Inna Pavlenko, PhD (Candidate of Pedagogical Sciences), teacher, Department of Sport Disciplines and Physical Education, Sumy State A. S. Makarenko Pedagogical University, 87, Romenska Str., Sumy, Ukraine

\title{
FORMING VALEOLOGICAL THINKING FOR ENHANCING STUDENTS’ ADAPTIVE CAPACITY WHEN STUDYING AT HIGHER EDUCATIONAL INSTITUTIONS
}

The article deals with the theoretical justification and development of methodological support for forming valeological thinking of students studying at higher educational institutions. As the result of scientific literature review and the experience in the sphere of education there have been distinguished a number of problems in the process of preparing pedagogical university students for valeological activities: irrational usage of curricula possibilities providing valeological integrated knowledge; the absence of the appropriate model of forming future teachers' valeological thinking as a necessary component of studying at higher educational institutions. Basing on the theoretical analysis special methods aimed at the formation of students' valeological thinking have been developed. Namely some changes in the curriculum of "Physical education" (as elective course) have been implemented; some tasks aimed at determining the level of students' theoretical knowledge and practical skills of valeological activities as well as some valeological thinking tests have been developed. The dynamics of students' valeological thinking maturity has been also studied. As the result of the research it has been revealed that the medium and high levels of valeological thinking, profound theoretical knowledge and developed practical skills of valeological activities contribute to the development of adaptive capacity of students. The further studies are aimed at the development of the model providing the formation of future teachers' valeological thinking as a necessary component of their studying at higher educational institutions.

Keywords: valeological thinking, adaptive capacity of students of higher educational institutions, professional training, theoretical basis, methodological support.

Подано до редакиії 15.08.2016

UDC: 378.172

\author{
Valerii Plisko, \\ Doctor of Pedagogy, professor, \\ Chernihiv National Pedagogical University named after T. Shevchenko, \\ 53, Hetmana Polubotka Str., Chernihiv, Ukraine, \\ Anita Sikura, \\ PhD (Candidate of Biological Sciences), associate professor, \\ National Pedagogical Dragomanov Univeristy, \\ 9, Pirohova Str., Kyiv, Ukraine, \\ Rostyslav Radziievskyi, \\ PhD (Candidate of Pedagogical Sciences), associate professor, \\ Institute of Administration of the State Guard of Ukraine, \\ Taras Shevchenko National University of Kyiv, \\ 60, Volodymyrska Str., Kyiv, Ukraine
}

\section{MOTOR ACTIONS MODELLING IN PHYSICAL EDUCATION}

The study is aimed at increasing the role of students' theoretical training when organizing their own motor actions at physical education classes. In such a way, practice is combined with theoretical knowledge; creative thinking is improved on the basis of the process of a certain motor image modeled by a student according to the goal set at the subconscious level; the effectiveness of the eventual results is provided due to rationality, capacity and heath-saving character of movements.

Keywords: motor actions, modelling, physical education, a student, creative thinking, muscle theory.

Problem statement. Detailed analysis of the characteristics of motor behaviour of students who take exercises has shown that their idea of purposeful motor actions and their meaning is insufficient, which makes it difficult to achieve desired result in setting the objective and to determine, at what stage mistakes appear. Physical jerks that were done in inappropriate manner in terms of time, their selection and technical inadequacy cause disbelief in one's capacity in doing exercises. There is the need for improvement of students' idea and image of the exercises before doing them. Acquiring skills of motor actions modelling according to the objective will provide motivation for their practical implementation.

Students engaged in sports should evaluate their own capabilities, level of training for the actions in terms of quality and quantity of characteristics, namely, in what 
ratio of these characteristics and at what stage they can carry out the action in an easy or more complicated manner. Moreover, it is reasonable to consider internal and external limits affecting their values. Internal limits include degree of manifestation of students' psychological tension, dynamic behaviour affecting the process in general. External limits can ease off or make an uncontrolled process more controllable. Efficiency depends on student's estimation of the required ratio of the component of the process. It is essential for decision-making.

However, in the curriculum, theory is usually introduced at several lectures and seminars that cover background information, classifications, requirements, characteristics, terminology, definitions, etc. Such disproportion affects considerably the quality of training, especially when knowledge is not organized in accordance with practice, and practice does not correspond to the requirements of reality. Practice should be confirmed by theoretical achievements and form abilities and skills on the basis of knowledge. Otherwise, the theory becomes doubtful and practice is of no effect. The content of the curriculum according to which students are trained is underbalanced; theoretical and practical parts are not coherent enough and do not correspond to competence requirements. Thus, the outlined problem is oriented at improvement of the process of students' physical education with the emphasis put on their theoretical comprehension of motor actions according to the objective and is research area of current interest.

Review of recent research works and publications. The learning model can be considered on the basis of activity theory, which was successfully done by P. Halperin and his colleagues in 50-60s. He proposed the theory of sequential acquisition of knowledge, formation of actions and concepts, which made training (specifically acquisition of the subject of training) a pedagogically controlled process. Conscious doing exercises for a particular purpose as well as idea of a regular shift of stages of actions acquisition has a special place in this theory [3].

The formation of abilities is held in several steps. At first, students become familiar with an ability, understand its meaning. Then comes the stage of its initial acquisition, and finally - individual and, with time, more precise performing of the learning activities.

Skills are the actions, components of which become automatic in the course of formation, in other words, they are characterized by being acquired well. Facilitated by skills, human activities are performed faster and more efficiently. Skills are formed in the process of applying knowledge on a certain mode of action by means of purposeful planned exercises. A skill is a necessary component of an ability. Compared to an ability, a skill is characterized by in such a level of acquisition when developed conscious self-control is necessary to some extent for proper performance of activities. An ability is the possibility to perform certain actions (activity) effectively. Consequently, motor abilities comprise a set of acquired skills and obtained knowledge that provide quality and efficiency of motor activity. Activity is the combination of an objective and a motive, when the main incentive is meeting a goal objective.

Experts offer a great number of definitions for the concept of "modelling". Some of them consider a model as an example of reproduction of characteristics peculiar to a certain object on another object that has been specially made for learning them. Others consider it as a means of reflecting a part of reality with the aim of its better understanding. On one hand, a model is an offspring of a theory, on the other hand - experimental part of research.

In A. Laputin and M. Nosok's opinion, activity modelling is the process of reflecting certain rules of its organization, namely gravitational interactions of human body and their reproduction with the help of special physical exercises or technical means with observance of fundamental principles of similarity theory and its principles of reciprocal unique correspondence of the model and simulated objects. In this case, physical exercises are used as means of targeted influence over human body; in the educational process they are proposed as motor exercises that comply with the purpose and tasks of effective training.

The above mentioned researchers think that the model of athletic technique is the object of any nature that makes it possible to substitute the motion under research or motor action (example of a technique) in the way that allows to obtain new knowledge concerning the technique.

According to the classical definition, a model is 1) an example; 2) the copying of an object in a reduced or enlarged view [4]. Modelling is the reproduction of characteristics peculiar to a certain object on another object (a model) that has been specially made for learning them.

According to H. Arziutov, a model is usually considered as a material or imaginary substitute for an object, which can be isomorphic (with observance of proportions) or isofunctional (with observance of functions), in other words, the one which makes it possible to study the structure or functions of an object.

S. Nemchynov defines a model as particular abstraction, a certain intermediate link between abstract thinking and current reality. When creating a model, a researcher can start out from observation, from practice to theory and in the opposite direction - from abstract theoretical knowledge to practice.

The model chosen for building according to "the character of representing parts of the original" (B. Hlynskyi) is the structural one, i.e. it represents a set of relations and links between its elements. The most favourable are the ones that are modelled in sports.

The aim of the article is to develop the mechanism of creative thinking in organizing students' motor actions when doing physical exercises.

The aim involves performing the following tasks:

1) to carry out analysis and provide personal assessment of motor actions modelling;

2) to develop schematic model of organizing certain motor actions for achieving the goal and to test its effectiveness experimentally. 
Research methods: method of scientific experiment, method of individual approach to creating a complex of motor actions, method of forming muscular memory, quiz method.

Major content. Teaching methods are considered advanced in case there is coherence between theory and practice. Theoretical material provides both general methodology for studying a subject and imaginative expression of actions. Combining theory and practice of motor actions makes it possible to form abilities of modelling them according to the objective.

Against the theoretical background, the most effective method of creating a model is the method of scientific experiment [1]. In the process of modeling, it is necessary to analyze motor actions, their effectiveness for achieving the objective and receive an appraisal of skilled professionals. The method of scientific experiment is one of the most important in motor actions reproduction [1; 2]. It consists of expert examination, expert experiment and comparative study. Expert review (analysis) is a sciencebased stage of the process of optimization of motor actions development according to the objective. Its task involves determining the image of the system of motor actions as a whole and their gradual dividing into the elements according to physical and psychological state, obstinacy, etc. Based on the data of expert review, it is possible to get an idea of the mechanism of motor action formation. In the current research, the method of scientific experiment that involves detailed acquisition of information on a certain motor action for conducting psychological monitoring was used.

Expert experiment (modelling) is practical reproduction of the general complex of motor actions considering circumstances and details that cause some doubt in the process of their study. The purpose of such an experiment is to determine practical performance of actions in accordance with the objective. In this case, the main objective is to elicit their health-improving influence and optimum sport indicator for each student individually.

Modelling is associated with the process of reasoning, which, in its turn, depends on the knowledge obtained, in other words, the level of theoretical preparedness in terms of motor actions organization, especially when the actions are motivated. Motor actions reasoning should answer the questions "what for?" (health-saving orientation), "why?" (the motive), "how?", "what consequences?" (result), "what are the structural properties of motor actions?" (connection between technical elements), etc. in correlation with readiness, physiological, psychological, mental and physical state of a student.

The actions performed are the result of thinking process. Intellectual support of actions is not targeted at thinking about technical performance, but at the necessity of correlation, analysis, comparison and making a choice concerning general decision.

Development of thinking is the most important qualitative function of a person, complex physiological process. Development of operational thinking is a time con- suming process, so it should be implemented in a consistent manner, performing simple tasks with their gradual complication. Observations have shown that long concentration or consideration of motor actions before their performance undermines the result. At the same time, making a decision on the subconscious level within 1.5-2 sec provides good results. Rational consideration or involvement of theoretical knowledge on motor actions should be stepwise. In addition to the above, they should be considered consciously for several times in order to reduce the number of repetitions and provide their subconscious performance.

At the final stage, it is desirable to combine consideration with performing motor actions' elements in a flexible manner. Each performed element coincides with the time of consideration.

In the course of teaching how to consider and master actions, motor memory becomes significant as long as it is the basis for development and consolidation of motor skills. From the practical point of view, it is reasonable to master methods of forming muscular memory and improve the process of consideration. When mastering new motor skills and using them in real life, a person also uses other types of memory.

Physiological mechanisms of information memorizing, its storage and reproduction are so complicated that, despite their active investigations, still, there is no generally recognized theory of memory. General theoretical foundation in this sphere is I. Pavlov's theory of conditioned nature of information storage and his idea of stimulating role reinforcement in the formation and consolidation of conditioned temporary links.

Practitioners with career in sport claim that at the first stage of training for muscular memory development, it is necessary to apply the method of "intense imagination", i.e. to form the system of movements that are borne in mind in one's thoughts.

There are three types of memory: visual, aural and motor. In the process of learning, knowledge is better absorbed when the process is watched and perceived aurally at the same time. In addition, it is important to train concentration, perception and the understanding of a subject. After that, motional process should be added [5]. Combination of three types of memory is effective for the development of motor memory.

When teaching motor actions modelling in physical education, it is reasonable to divide the content of the subject into two interrelated parts: theoretical and practical; use the method of individual and person-oriented approach to the development of motor actions complex and method of muscular memory formation. A student makes a decision about the most appropriate way of modelling and practical implementation of a motor action: in health-saving or health-providing way, for sporting achievement or the formation of physical qualities. According to the objective, it possible to determine technical peculiarities of movements, their structural properties, form, space-and-time characteristics, amplitude, trajecto- 
ry, interaction of supporting reactions, arrangement of muscles, vigour, etc. Each element of motor actions is interrelated with the other in terms of succession and concurrence. Having developed the theoretical model of motor actions, the students can go ahead with its practical implementation. All the indicators are analyzed with the emphasis on possible difficulties for determining the necessity for heightened attention and dividing actions into preparatory and basic ones. All the data should correspond to the student's state in terms of his/her readiness for performing the complex. For example, according to the determined orientation, motive, dosing, mode, preliminaries are determined (pic. 1).

In order to enhance the efficiency of various motional complexes used in physical education, a subexperiment illustrated by long jumping and high jumping was conducted.

Quiz method was used: the participant had to answer the questions on the basis of theoretical knowledge. Ac- cording to verbal characteristics of movements, sequence of transitions from one movement to another as well as time spent on giving the answer were taken into account. Latent time from the moment when the question was asked till the moment when the full answer was finished was estimated. Quickness, clearness and concretion were also considered.

Theory consisted of the information on movements' effectiveness, terminology, space-and-time characteristics, biomechanical analysis and projection of movements themselves.

After theoretical training at the first lesson, coordinated work at the second one was observed. The participants who did exercises on the basis of knowledge obtained were able to compensate the time required for their practical mastering of technical activities and achieved good results compared to initial data. The effectiveness was $40 \%$.

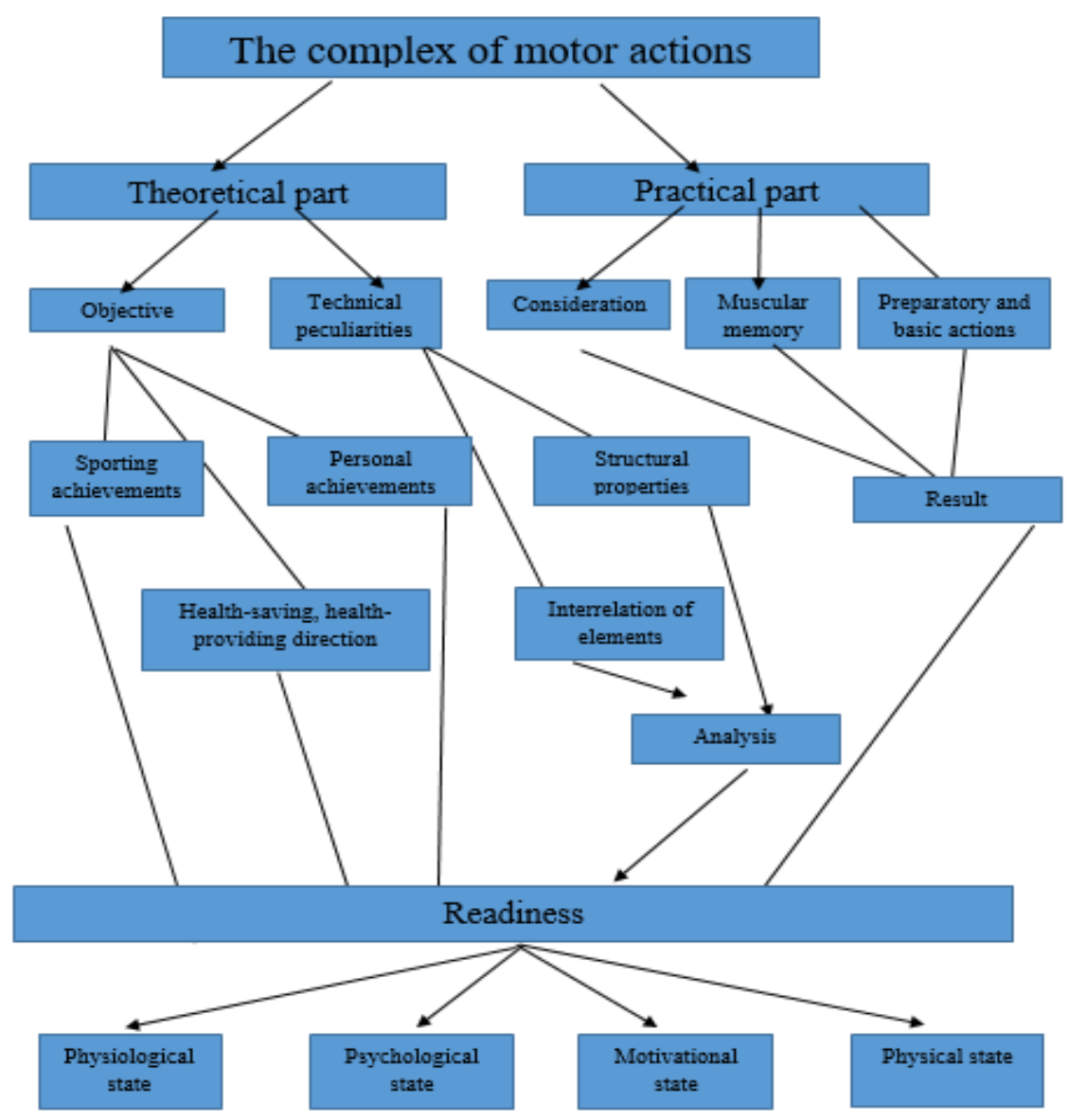

Pic.1. Motor actions modelling in physical education

Conclusions and prospects for further research. Review of studies of head researchers in physical education has lead to general understanding of the need for the improvement of teaching physical education in terms of efficient arrangement of topics of the lessons. Reasonable use of didactic principles (from knowledge and abilities to skills) makes physical education classes efficient. Bal- anced saturation of the curriculum with theory and practice improves consistency, systemacity, understandability. When developing teaching methods, it is reasonable to take advantage of interrelations between theoretical and practical exploratory work, to systemize knowledge for a particular situation and to determine actions that do not cause doubt. 
Consequently, the formation of abilities and skills requires much time. However, rationality of the actions mastered provides an opportunity for correcting the curriculum; the actions tested through practice that have been proven theoretically are considered as the process of gaining and transferring experience.

Prospects for further research involve the search for the most efficient form of educational process improve-

\section{ЛІТЕРАТУРА}

1. Берштейн Н. А. О построении движений / Н. А. Бернштейн. - М. : Медгиз, 1947. - 255 с.

2. Брушлинский А. В. Мышление и прогнозирование / А. В. Брушлинский. - М. : Мысль, 1979. - 230 c.

3. Гальперин П. Я. Основные результаты исследования по проблеме «Формирование умственных действий и понятий»: доклад, обобщающий исследования, представленные на соискание ученой степени

\section{REFERENCES}

1. Bershteyn, N. A. (1947). O postroenii dvizheniy [Motion synthesis]. Moscow: Medgiz [in Russian].

2. Brushlinskiy, A. V. (1979). Myshlenie $i$ prognozirovanie [Thinking and forecating]. Moscow: Mysl [in Russian].

3. Galperin, P. Ya. (1965). Osnovnye rezultaty issledovaniya po probleme "Formirovanie umstvennykh deystviy $i$ ponyatiy»: doklad, obobschayushchiy issledovaniya, predstavlennye na soiskanie uchenoy stepeni doktora pedagogicheskikh nauk [Fundamental results of research on the issue of forming mental efforts and concepts: report representing the research works

ment due to psychological monitoring and mindset trainings for faster and more effective acquisition of each particular component of motor action, which is possible due to the impact on subconscious mind and consistent consolidation at the stage of transition from knowledge to abilities.

доктора педагогических наук / П. Я. Гальперин. - М. : МГУ, 1965.

4. Захаров Е. Н. и др. Энциклопедия физической подготовки : Методические основы развития физических качеств / Е. Н. Захаров, А. В. Карасев, А. А. Сафонов. - М. : ОЛентос, 1994. - 368 с.

5. Пономарев Н. И., Ильинич В. И., Гудзенко И. Р. Физической подготовке - профессиональную направленность // Вести высшей школы. -1975. - № 8. - C. 67-69.

submitted for a doctor's degree in pedagogy]. Moscow: MGU [in Russian].

4. Zakharov, Ye. N., Karasev, A. V., \& Safonov, A. A. (1994). Entsiklopediya fizicheskoy podgotovki: Metodicheskie osnovy razvitiya fizicheskikh kachestv [Physical training encyclopedia: methodic bases for physical qualities development]. Moscow: OLentos [in Russian].

5. Ponomarev, N. I., Ilinich, V. I., \& Gudzenko, I. R. (1975). Fizicheskoy podgotovke - professionalnuyu napravlennost [Professional direction of physical training]. Vesti vysshey shkoly - News of higher education, 8, 67-69 [in Russian].

Валерій Іванович Плиско, доктор педагогічних наук, професор, Чернігівський національний педагогічний університет імені Т. Г. Шевченка, вул. Гетьмана Полуботка, 53, м. Чернісів, Украӥна, Аніта Йосипівна Сікура, кандидат біологічних наук, доцент, Наиіональний педагогічний університет імені М. П. Драгоманова, вул. Пирогова, 9, м. Київ, Україна,

Ростислав Михайлович Радзісвський, кандидат педагогічних наук, дочент, Інститут Управління державної охорони Київського начіонального університету імені Тараса Шевченка, вул. Володимирська, 60, м. Київ, Украӥна

\section{МОДЕЛЮВАННЯ РУХОВИХ ДІЙ У ФІЗИЧНОМУ ВИХОВАННІ}

Дослідження спрямовано на підвищення ролі теоретичної підготовки студентів в організації власних рухових дій на заняттях із фізичного виховання. Було поставлено наступні завдання: провести аналіз і дати особисту оцінку процесу моделювання рухових дій; розробити схематичну модель організації рухових дій відповідно до поставленої мети і експериментально перевірити ії ефективність. 3 метою підвищення ефективності різних рухових комплексів, використовуваних у фізичному вихованні, було проведено приватний експеримент на прикладі стрибків у довжину і висоту. Використовувався метод бліц-опитування, коли учасник на підставі теоретичних знань дає відповідь на поставлене запитання. На підставі усної характеристики рухів розраховувалася послідовність переходу від одних рухів до інших, а також весь час, використаний на відповідь. Також оцінювався латентний період від моменту, коли було 
поставлено питання, до завершення повної відповіді. Враховувалася швидкість, чіткість і конкретність. Після теоретичної підготовки на першому занятті відзначалася злагоджена робота на другому (практичному) занятті. Учасники, які виконували завдання на основі отриманих знань, зуміли компенсувати час на практичне засвоєння технічних дій $\mathrm{i}$ досягли високих показників у порівнянні з вихідними даними. Ефективність становила 40\%. Проведене дослідження дозволило зробити наступні висновки. Необхідним є вдосконалення викладання фізичного виховання на основі раціонального розподілу тематики занять. Використання дидактичних принципів від знань і умінь до навичок забезпечує ефективність занять 3 фізичного виховання. Пропорційне насичення програми теоретичними і практичними розділами дозволяє підвищити послідовність, системність і доступність. Під час розробки методики навчання доцільно враховувати взаємозв'язок теоретичних і практичних напрацювань, систематизувати знання для конкретної ситуації і визначити дії, які не викликають сумнівів.

Ключові слова: рухові дії, моделювання, фізичне виховання, студент, образне мислення, м'язова пам'ять.

Валерий Иванович Плиско,

доктор педагогических наук, профессор, Черниговский национальный педагогический университет имени Т. Г. Шевченко, ул. Гетьмана Полуботка, 53, г. Чернигов, Украина,

Анита Иосифовна Сикура, кандидат биологических наук, дочент, Национальный педагогический университет имени М. П. Драгоманова, ул. Пирогова, 9, г. Киев, Украина, Ростислав Михайлович Радзиевский, кандидат педагогических наук, дочент, Институт Управления государственной охраны Киевского национального университета имени Тараса Шевченко, ул. Владимирская, 60, г. Киев, Украина

\section{МОДЕЛИРОВАНИЕ ДВИГАТЕЛЬНЫХ ДЕЙСТВИЙ В ФИЗИЧЕСКОМ ВОСПИТАНИИ}

Исследование направлено на повышение роли теоретической подготовки студентов в организации собственных двигательных действий на занятиях по физическому воспитанию. Были поставлены следующие задачи: провести анализ и дать личную оценку процессу моделирования двигательных действий; разработать схематическую модель организации двигательных действий согласно поставленной цели и экспериментально проверить ее эффективность. С целью повышения эффективности различных двигательных комплексов, используемых в физическом воспитании, был проведен частный эксперимент на примере прыжков в длину и высоту. Использовался метод блицопроса, когда участник на основании теоретических знаний дает ответ на поставленный вопрос. На основании устной характеристики движений рассчитывалась последовательность перехода от одних движений к другим, а также все использованное время на ответ. Также оценивался латентный период от момента, когда был задан вопрос, до завершения полного ответа. Учитывалась скорость, четкость и конкретность. После теоретической подготовки на первом занятии отмечалась согласованная работа на втором (практическом) занятии. Участники, выполняющие задание на основе полученных знаний, сумели компенсировать время на практическое усвоение технических действий и достигли высоких показателей по сравнению с исходными данными. Эффективность составляла 40 \%. Проведенное исследование позволило сделать следующие выводы. Необходимо усовершенствовать преподавание физического воспитания на основе рационального распределения тематики занятий. Использование дидактических принципов от знаний и умений к навыкам обеспечивает эффективность занятий по физическому воспитанию. Пропорциональное насыщение программы теоретическими и практическими разделами позволяет повысить последовательность, системность и доступность. При разработке методики обучения целесообразно учитывать взаимосвязь теоретических и практических наработок, систематизировать знания для конкретной ситуации и определить действия, не вызывающие сомнений.

Ключевые слова: двигательные действия, моделирование, физическое воспитание, студент, образное мышление, мышечная память.

Подано до редакиії 15.08.2016 